Article

\title{
Synthesis of FER zeolite with piperidine as structure-directing agent and its catalytic application
}

\author{
Weifeng Chu a,b, Fucun Chen a, Ce Guo a,b, Xiujie Li a,\#, Xiangxue Zhu a, Yang Gao a, Sujuan Xie a, \\ Shenglin Liu a , Nan Jiang c, Longya Xu a,* \\ a Dalian National Laboratory for Clean Energy, Dalian Institute of Chemical Physics, Chinese Academy of Sciences, Dalian 116023, Liaoning, China \\ b University of Chinese Academy of Sciences, Beijing 100049, China \\ c Nanjing Rongxin Chemical Co., Ltd., Nanjing 210047, Jiangsu, China
}

\section{A R T I C L E I N F}

\section{Article history:}

Received 23 July 2017

Accepted 24 August 2017

Published 5 November 2017

\section{Keywords:}

FER zeolite

Piperidine

Crystallization process

MWW zeolite

Skeletal isomerization

\begin{abstract}
A B S T R A C T
The synthesis of ferrierite (FER) zeolite using piperidine as an organic structure-directing agent was investigated. X-ray diffraction, X-ray fluorescence, $\mathrm{N}_{2}$-adsorption, and scanning electron microscopy were used to characterize the crystal phases, textural properties, and particle morphologies of the zeolite samples. The crystallization behavior of the FER zeolite was found to be directly related to crystallization temperature. At $150{ }^{\circ} \mathrm{C}$, pure FER phase was observed throughout crystallization. At 160-170 ${ }^{\circ} \mathrm{C}$, MWW phase appeared first and gradually transformed into FER phase over time, indicating that the FER phase was thermodynamically favored. In the piperidine- $\mathrm{Na}_{2} \mathrm{O}-\mathrm{H}_{2} \mathrm{O}$ synthetic system, alkalinity proved to be the crucial factor determining the size and textural properties of FER zeolite. Furthermore, the obtained FER samples exhibited good catalytic performance in the skeletal isomerization of 1-butene.
\end{abstract}

(C) 2017, Dalian Institute of Chemical Physics, Chinese Academy of Sciences. Published by Elsevier B.V. All rights reserved.

\section{Introduction}

Ferrierite (FER) zeolite is a medium-pore zeolite with two perpendicular intersecting channels, namely an 8-membered ring (MR) channel $(0.35 \mathrm{~nm} \times 0.48 \mathrm{~nm})$ along the [010] direction and a 10-MR channel $(0.42 \mathrm{~nm} \times 0.54 \mathrm{~nm})$ along the [001] direction [1]. FER zeolite is an industrialized zeolite that has been successfully applied as a catalyst to the skeletal isomerization of 1-butene [2-6]. FER zeolite has also been used in other reactions, including nitrous oxide decomposition and reduction [7,8], dimethyl ether carbonylation [9-11], methanol-toolefin (MT0) conversion [12], alkane hydroisomerization [13], and $n$-paraffin cracking $[14,15]$.
FER zeolite is usually synthesized with the assistance of organic structure-directing agents (OSDAs), which are generally organic amine compounds, such as ethylenediamine [16,17], pyrrolidine $[6,18,19]$, pyridine $[20,21]$, and cyclohexylamine [22]. Furthermore, oxygen-containing compounds, such as tetrahydrofuran, can be used to direct the synthesis of FER zeolite $[23,24]$. FER zeolite can also be synthesized using two organic molecules of different sizes as co-OSDAs, with the resultant materials showing unique physical, chemical or catalytic properties. Hierarchical FER zeolite was synthesized using piperidine (PI) and tetramethylammonium hydroxide as co-OSDAs, leading to more than three-fold external surface area and better catalytic performance in catalytic low-density polyethylene

\footnotetext{
* Corresponding author. Tel/Fax:+86-411-8437 9279; E-mail: lyxu@dicp.ac.cn

\# Corresponding author. Tel/Fax: +86-411-8437 9279; E-mail: xiujieli@dicp.ac.cn

This work was supported by the National Natural Science Foundation of China (21376235) and Natural Science Foundation of Liaoning Province (201602740).

DOI: 10.1016/S1872-2067(17)62906-1 | http://www.sciencedirect.com/science/journal/18722067 | Chin. J. Catal., Vol. 38, No. 11, November 2017
} 
cracking compared to the bulk zeolite [25]. Hierarchical FER zeolite nanosheet assemblies with ball-shaped morphologies have been prepared using an organosilane surfactant, 3-(trimethoxysilyl)propyl octadecyl dimethyl ammonium chloride, and pyrrolidine as co-OSDAs. Compared with conventional FER zeolite, these assemblies showed greatly improved catalytic activity in the benzylation of toluene with benzyl chloride [26]. Recently, FER zeolite was synthesized using a novel combination of OSDAs, namely 1,6-bis( $N$-methylpyrrolidinium)hexane and tetramethylammonium [27].

Previously, Jongkind et al. [28] found that FER zeolite was synthesized using PI as an OSDA during the preparation of mordenite (MOR) zeolite using saturated cyclic amines as OSDAs. However, these products were always contaminated with the MOR phase. After that, FER zeolite was synthesized by solid-state recrystallization of aluminum-containing magadiite [29] and kanemite [30]. Generally, it is necessary to prepare the raw materials, magadiite or kanemite, before recrystallization, which makes this synthetic approach more complex. Furthermore, the products are always contaminated with magadiite or quartz. Wu et al. [31] found that FER zeolite was obtained from the crystallization of MCM-22 (MWW type) zeolite when the silica/aluminum molar ratio $\left(\mathrm{SAR}, \mathrm{SiO}_{2} / \mathrm{Al}_{2} \mathrm{O}_{3}\right)$ was lower than 25. However, synthesis of FER zeolite using PI as an OSDA in a simple and workable way is still needed to be resolved.

In this work, we focused on optimizing the synthetic conditions of FER zeolite using PI as an OSDA. The entire crystallization process at different temperatures was monitored by X-ray diffraction (XRD) and scanning electron microscopy (SEM). The influence of initial gel composition (alkalinity, water content, and SAR) on the crystal phase and morphology of the products was investigated in detail. The optimal synthetic conditions for FER zeolite using PI as an OSDA are summarized. Furthermore, the obtained samples were evaluated as catalysts in the skeletal isomerization of 1-butene.

\section{Experimental}

\subsection{Zeolite synthesis}

FER zeolite was synthesized using PI as an OSDA under traditional hydrothermal conditions. In a typically procedure, sodium aluminate solution (16.8 wt $\% \mathrm{Al}_{2} \mathrm{O}_{3}, 24.2$ wt $\% \mathrm{Na}_{2} \mathrm{O}$, homemade), deionized water, sodium hydroxide $(96.0 \%$, Sinopharm Chemical Reagent Co., Ltd.), PI (99.0\%, Sinopharm Chemical Reagent Co., Ltd.), and silica sol (29.7 wt\% $\mathrm{SiO}_{2}$, Qingdao Haiyang Chemical Co., Ltd.) were added into a Teflonlined stainless-steel autoclave. The batch composition obtained in the initial gel mixture was $2.1 \mathrm{Na}_{2} \mathrm{O}: 0.55 \mathrm{Al}_{2} \mathrm{O}_{3}: 20 \mathrm{SiO}_{2}: 3.2 \mathrm{PI}$ : $280 \mathrm{H}_{2} \mathrm{O}$. After stirring for $30 \mathrm{~min}$, the mixture was heated under rotation $(60 \mathrm{rpm})$ at a specified reaction temperature for a given time. The reaction was quenched with tap water and the product was separated by repeated centrifugation several times until the solution was neutral. The solid was dispersed in water again and dried at $120^{\circ} \mathrm{C}$ overnight.

After removing the OSDA by calcination at $540{ }^{\circ} \mathrm{C}$ for $3 \mathrm{~h}$, the sodium-form zeolite was exchanged to the ammonium form by treatment with $\mathrm{NH}_{4} \mathrm{NO}_{3}$ solution $(1.0 \mathrm{~mol} / \mathrm{L})$ at $80^{\circ} \mathrm{C}$ for $2 \mathrm{~h}$ with stirring. This procedure was repeated twice for each sample. The sample was then washed with deionized water three times, dried, and calcined at $520{ }^{\circ} \mathrm{C}$ for $3 \mathrm{~h}$ to afford the proton-form zeolite.

\subsection{Characterization}

Powder XRD data were collected on a PANalytical X'Pert PRO diffractometer using $\mathrm{Cu} K_{\alpha}$ monochromatized radiation operating at $40 \mathrm{kV}$ and $40 \mathrm{~mA}$. The samples were scanned in the $2 \theta$ range of $5^{\circ}-50^{\circ}$ with a step size of $0.02^{\circ}$. The relative crystallinity (RC) of samples was calculated from the characteristic peak heights $\left(2 \theta=9.3^{\circ} \pm 0.1^{\circ}, 22.3^{\circ} \pm 0.1^{\circ}, 23.5^{\circ} \pm 0.1^{\circ}\right.$, $24.3^{\circ} \pm 0.1^{\circ}, 25.2^{\circ} \pm 0.1^{\circ}, 25.7^{\circ} \pm 0.1^{\circ}$, and $28.5^{\circ} \pm 0.1^{\circ}$ ). The sample (S15) with an initial gel composition of $3.0 \mathrm{Na}_{2} \mathrm{O}$ : $0.50 \mathrm{Al}_{2} \mathrm{O}_{3}: 20 \mathrm{SiO}_{2}: 3.2 \mathrm{PI}: 280 \mathrm{H}_{2} \mathrm{O}$ synthesized at $160{ }^{\circ} \mathrm{C}$ for $48 \mathrm{~h}$ was chosen as the reference sample. Chemical compositions were analyzed using a Philips Magix 601 X-ray fluorescence (XRF) spectrometer. Crystal morphology and particle size were observed by SEM using FEI Quanta-200F and Hitachi SU1510 microscopes. Samples were coated with gold before testing. $\mathrm{N}_{2}$ adsorption/desorption experiments were carried out at -196 ${ }^{\circ} \mathrm{C}$ on a Micromeritics ASAP-2020 HD88 instrument. Prior to analysis, samples were degassed at $350^{\circ} \mathrm{C}$ for $10 \mathrm{~h}$.

\subsection{Catalyst evaluation}

The 1-butene skeletal isomerization reactions were carried out at atmospheric pressure on a continuous-flow fixed bed microreactor with an inner diameter of $6 \mathrm{~mm}$. In a typical procedure, catalyst $(0.50 \mathrm{~g})$ was activated under flowing $\mathrm{N}_{2}(20$ $\mathrm{mL} / \mathrm{min}$ ) at $500{ }^{\circ} \mathrm{C}$ for $2 \mathrm{~h}$ and then cooled to $400{ }^{\circ} \mathrm{C}$. The mixture of 1-butene and $\mathrm{N}_{2}$ was then fed into the fixed bed. The 1-butene/ $\mathrm{N}_{2}$ molar ratio was $1 / 1$ and the weight hourly space velocity (WHSV) of 1-butene was $8 \mathrm{~h}^{-1}$. The products were analyzed using an online gas chromatograph (Agilent 7890B) equipped with a flame ionization detector (FID) and an $\mathrm{Al}_{2} \mathrm{O}_{3}$ capillary column.

\section{Results and discussion}

\subsection{Crystallization process of FER zeolite}

Crystalline phases of zeolites are sensitive to crystallization temperature and time due to the metastable nature of zeolites [32]. Initial gels were crystallized at different temperatures for a certain time, and the XRD patterns of the corresponding samples are shown in Fig. 1. Only FER zeolite appeared in the crystallization process when crystallized at $150{ }^{\circ} \mathrm{C}$ (Fig. 1(a)). At $160{ }^{\circ} \mathrm{C}$ and $170{ }^{\circ} \mathrm{C}$, the crystallization processes were significantly different from that at $150{ }^{\circ} \mathrm{C}$. MWW and FER composite zeolites were obtained when initial gels were heated at $160{ }^{\circ} \mathrm{C}$ for $32 \mathrm{~h}$. When the crystallization time was extended to $36 \mathrm{~h}$, both the MWW and FER zeolite contents increased, as shown in Fig. 1(b). As the crystallization time was further increased, FER zeolite gradually began to dominate the product and MWW 

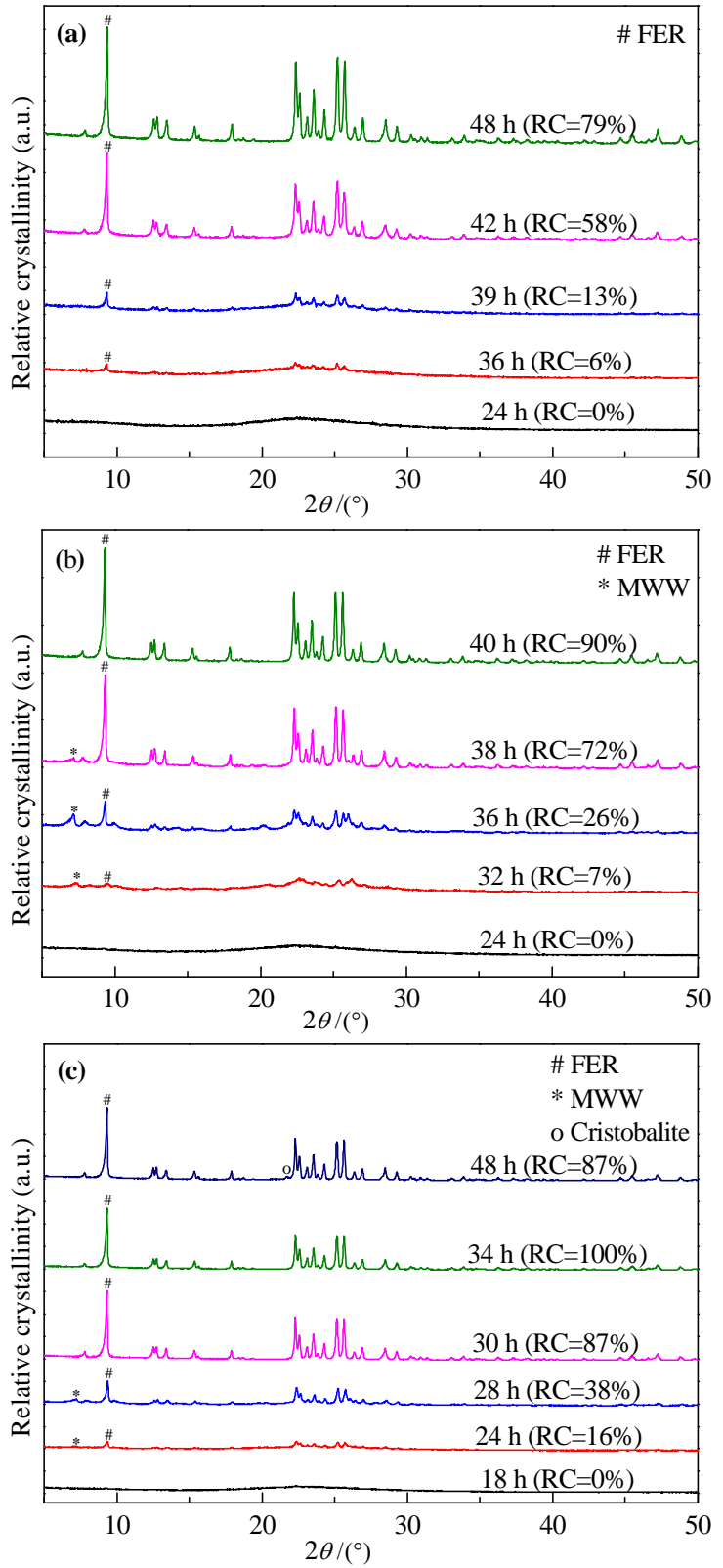

Fig. 1. XRD patterns of samples crystallized at different temperatures for a specified time with initial gel composition of $2.1 \mathrm{Na}_{2} \mathrm{O}: 0.55 \mathrm{Al}_{2} \mathrm{O}_{3}$ : $20 \mathrm{SiO}_{2}: 3.2 \mathrm{PI}: 280 \mathrm{H}_{2} \mathrm{O}$. (a) $150{ }^{\circ} \mathrm{C}$; (b) $160{ }^{\circ} \mathrm{C}$; (c) $170{ }^{\circ} \mathrm{C}$.

zeolite completely disappeared, with pure FER zeolite obtained after $40 \mathrm{~h}$. As PI could direct the synthesis of MWW zeolite $[31,33]$ and MWW zeolite could transform into FER zeolite [34-36], it was reasonable that MWW zeolite was present in the crystallization process of FER zeolite as a metastable phase that finally transformed into FER zeolite. Furthermore, high temperatures favored the crystallization of MWW zeolite in this system. This was further illustrated by the crystallization process at $170{ }^{\circ} \mathrm{C}$, which was similar to that at $160{ }^{\circ} \mathrm{C}$, while the crystallization rate was significantly increased and the FER zeolite was well crystallized after $34 \mathrm{~h}$. With the crystallization time further extended to $48 \mathrm{~h}$, the product was contaminated with cristobalite as an impurity phase, indicated by the peak at $21.7^{\circ}$ in the corresponding XRD pattern.
Crystallization curves of FER zeolite at different temperatures are shown in Fig. 2. The induction period was approximately $34 \mathrm{~h}$ when the initial gel mixture was crystallized at 150 ${ }^{\circ} \mathrm{C}$. Well-crystallized FER zeolite was obtained when the crystallization time was extended to $45 \mathrm{~h}$. Further extending the crystallization time had little effect on the RC of the FER zeolite. When the crystallization temperature was increased to $160{ }^{\circ} \mathrm{C}$, a crystallization curve similar to that at $150{ }^{\circ} \mathrm{C}$ was obtained, but with the induction period shortened to $26 \mathrm{~h}$. Well-crystallized FER zeolite was obtained after $40 \mathrm{~h}$. When the temperature was further increased to $170{ }^{\circ} \mathrm{C}$, the induction period was just $18 \mathrm{~h}$ and FER zeolite was well crystallized after $34 \mathrm{~h}$. However, with further increasing crystallization time, the RC of the FER zeolite declined rapidly. As mentioned previously, a peak not attributed to FER zeolite was found in the XRD pattern of the sample crystallized for $48 \mathrm{~h}$ (Fig. 1(c)), indicating that the decrease in RC was due to FER zeolite transforming into cristobalite. This was similar to the results reported by Pál-Borbély et al [30], who found that FER zeolite transformed into quartz over time when the crystallization temperature was above 147 ${ }^{\circ} \mathrm{C}$ using a solid-state recrystallization method.

SEM images were taken after crystallization at $160{ }^{\circ} \mathrm{C}$ (Fig. 3). An amorphous phase was obtained after crystallization for $24 \mathrm{~h}$. Extending the crystallization time to $32 \mathrm{~h}$ afforded aggregates consisting of numerous platelets, which is the typical morphology of MWW zeolite. When the crystallization time was $36 \mathrm{~h}$, block FER zeolite was clearly observed on the surface of the MWW aggregates. After $38 \mathrm{~h}$, these MWW aggregates had largely disappeared, and the product was mainly composed of block FER zeolite. Pure FER zeolite was obtained after crystallization for $40 \mathrm{~h}$. These observations were in accordance with the XRD results.

\subsection{Effect of alkalinity on the synthesis of FER zeolite}

XRD patterns of samples synthesized at different alkalinities are shown in Fig. 4, and detailed synthetic parameters are listed in Table 1. FER zeolites without any impurity phase were obtained using $\mathrm{Na}_{2} \mathrm{O} / \mathrm{SiO}_{2}$ molar ratios of $0.090-0.140$. When the $\mathrm{Na}_{2} \mathrm{O} / \mathrm{SiO}_{2}$ ratio was lower (S1), no FER phase was found, with the products mainly consisting of MWW and MTN phases.

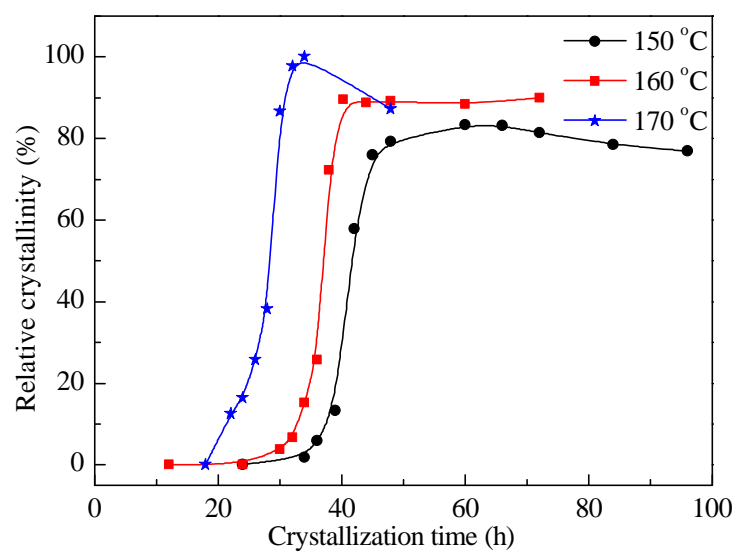

Fig. 2. Crystallization curves of FER zeolites at different temperatures with initial gel composition of $2.1 \mathrm{Na}_{2} \mathrm{O}: 0.55 \mathrm{Al}_{2} \mathrm{O}_{3}: 20 \mathrm{SiO}_{2}: 3.2 \mathrm{PI}: 280 \mathrm{H}_{2} \mathrm{O}$. 

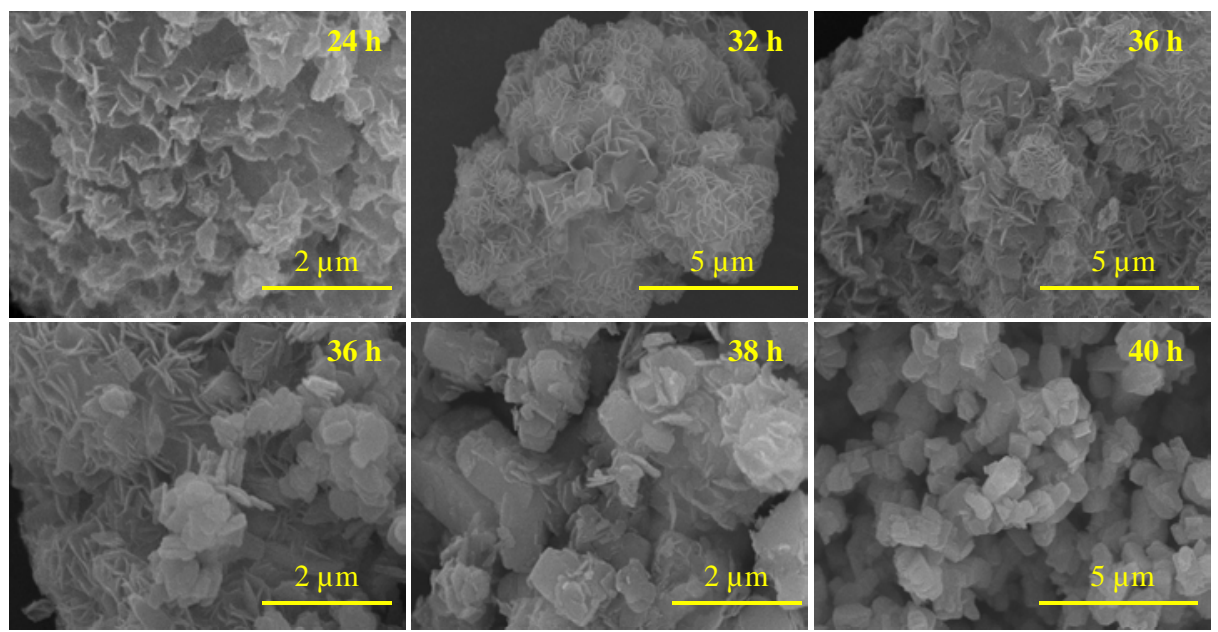

Fig. 3. SEM images of samples crystallized over different time at $160^{\circ} \mathrm{C}$.

In contrast, FER zeolite was obtained at a higher alkalinity $\left(\mathrm{Na}_{2} \mathrm{O} / \mathrm{SiO}_{2}=0.150\right)$, but was contaminated with MOR phase. Furthermore, samples were crystallized at different alkalinities when the SAR was 30.3 and 40.0 (Table 1). Pure FER zeolite was synthesized using $\mathrm{Na}_{2} \mathrm{O} / \mathrm{SiO}_{2}$ molar ratios of $0.105-0.150$ (initial gel SAR $=40.0$ ), which were slightly higher than those used to prepare FER zeolite with an initial gel SAR of 36.4. When the alkalinity was increased, a mixture (S16) of FER and MOR was obtained, which was also observed for initial gels with low SARs (S6 and S10). However, FER zeolite doped with MTN phase (S11) was obtained at low alkalinity, which was different from the case at low alkalinity when the initial gels had an SAR of 36.4. The alkalinity used to synthesize FER zeolite was lower $\left(\mathrm{Na}_{2} \mathrm{O} / \mathrm{SiO}_{2} \leq 0.125\right)$ when the initial gels had an SAR of 30.3.

Product morphology was closely related to alkalinity. SEM images of FER zeolites synthesized at different alkalinities are

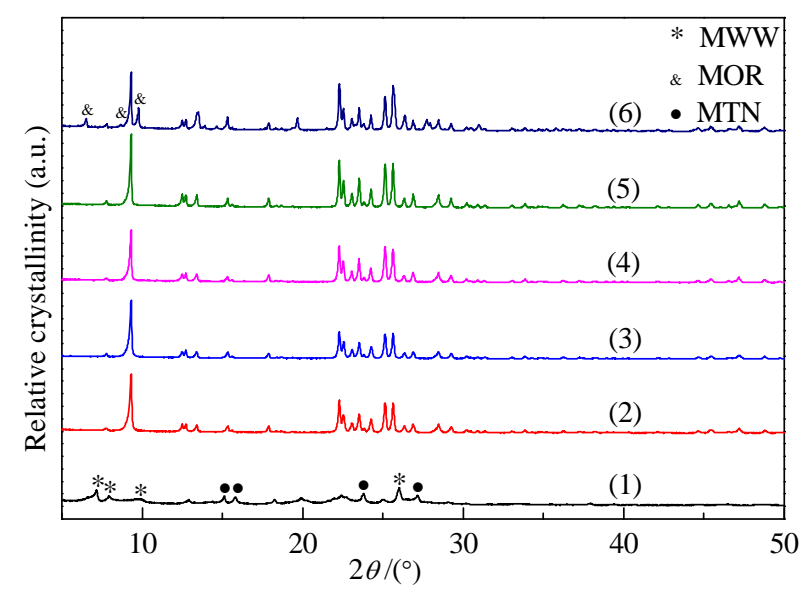

Fig. 4. XRD patterns of samples synthesized with different $\mathrm{Na}_{2} \mathrm{O} / \mathrm{SiO}_{2}$ ratios. (1) 0.075 (S1); (2) 0.090 (S2); (3) 0.105 (S3); (4) 0.125 (S4); (5) 0.140 (S5); (6) 0.150 (S6).

Table 1

Synthetic parameters and properties of the obtained samples. ${ }^{a}$

\begin{tabular}{|c|c|c|c|c|c|c|}
\hline \multirow{2}{*}{ Sample } & \multicolumn{3}{|c|}{ Initial gel } & \multicolumn{3}{|c|}{ Product } \\
\hline & $\mathrm{SiO}_{2} / \mathrm{Al}_{2} \mathrm{O}_{3}$ & $\mathrm{Na}_{2} \mathrm{O} / \mathrm{SiO}_{2}$ & $\mathrm{H}_{2} \mathrm{O} / \mathrm{SiO}_{2}$ & Phase & $\mathrm{RC}^{\mathrm{b}}(\%)$ & $\mathrm{SiO}_{2} / \mathrm{Al}_{2} \mathrm{O}_{3}$ \\
\hline S1 & 36.4 & 0.075 & 14.0 & $\mathrm{MWW}+\mathrm{MTN}$ & 0 & - \\
\hline $\mathrm{S} 2$ & 36.4 & 0.090 & 14.0 & FER & 88 & 29.0 \\
\hline S3 & 36.4 & 0.105 & 14.0 & FER & 91 & - \\
\hline S4 & 36.4 & 0.125 & 14.0 & FER & 96 & - \\
\hline S5 & 36.4 & 0.140 & 14.0 & FER & 96 & 26.5 \\
\hline S6 & 36.4 & 0.150 & 14.0 & $\mathrm{FER}+\mathrm{MOR}$ & 74 & - \\
\hline S7 & 30.3 & 0.090 & 14.0 & FER & 86 & - \\
\hline S8 & 30.3 & 0.105 & 14.0 & FER & 85 & - \\
\hline S9 & 30.3 & 0.125 & 14.0 & FER & 87 & - \\
\hline S10 & 30.3 & 0.140 & 14.0 & $\mathrm{FER}+\mathrm{MOR}$ & 89 & - \\
\hline S11 & 40.0 & 0.090 & 14.0 & $\mathrm{FER}+\mathrm{MTN}$ & 67 & - \\
\hline S12 & 40.0 & 0.105 & 14.0 & FER & 90 & - \\
\hline S13 & 40.0 & 0.125 & 14.0 & FER & 93 & - \\
\hline S14 & 40.0 & 0.140 & 14.0 & FER & 98 & - \\
\hline S15 & 40.0 & 0.150 & 14.0 & FER & 100 & - \\
\hline S16 & 40.0 & 0.160 & 14.0 & $\mathrm{FER}+\mathrm{MOR}$ & 62 & - \\
\hline S17 & 36.4 & 0.105 & 8.5 & $\mathrm{FER}+\mathrm{U}^{\mathrm{c}}$ & 71 & - \\
\hline S18 & 36.4 & 0.105 & 25.0 & $\mathrm{Am}^{\mathrm{d}}$ & 0 & - \\
\hline S19 e & 36.4 & 0.105 & 25.0 & FER & 73 & - \\
\hline $\mathrm{S} 20$ & 36.4 & 0.105 & 35.0 & $\mathrm{Am}$ & 0 & 一 \\
\hline
\end{tabular}

a Samples were synthesized with initial gel compositions of $x \mathrm{Na}_{2} \mathrm{O}: y \mathrm{Al}_{2} \mathrm{O}_{3}: 20 \mathrm{SiO}_{2}: 3.2 \mathrm{PI}: 2 \mathrm{H}_{2} \mathrm{O}$ under hydrothermal conditions at $160{ }^{\circ} \mathrm{C}$ for $48 \mathrm{~h}$.

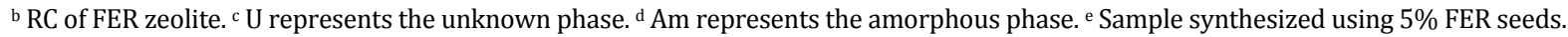


shown in Fig. 5. Well-dispersed lamellar samples were obtained at low alkalinity $\left(\mathrm{S} 2, \mathrm{Na}_{2} \mathrm{O} / \mathrm{SiO}_{2}=0.090\right)$, and the crystal size ranged from $0.5 \mu \mathrm{m}$ to $1.0 \mu \mathrm{m}$. The morphology of the sample (S5) synthesized at high alkalinity was very different to that of S2, showing smaller primary particles $(0.4-0.5 \mu \mathrm{m})$ and closer stacking. The SARs of the two products were also different, decreasing from 29.0 to 26.5 when the $\mathrm{Na}_{2} \mathrm{O} / \mathrm{SiO}_{2}$ ratio was increased from 0.090 to 0.140 (Table 1).

$\mathrm{N}_{2}$ adsorption/desorption isotherms of FER zeolites synthesized at different alkalinities are shown in Fig. 6, all of which showed type-I $\mathrm{N}_{2}$ adsorption isotherms. Detailed data of the textural properties are summarized in Table 2. The micropore volumes of the three samples were large and similar to reported values [17], indicating that all three samples were well crystallized. The external surface area of S2 was larger than that of S5 (38 m²/g vs. $\left.27 \mathrm{~m}^{2} / \mathrm{g}\right)$, which seemed abnormal because the crystal size of S2 (Fig. 5(a) and (b)) was larger than that of S5 (Fig. 5(c) and (d)). Notably, the crystal particles of S2 were loosely stacked, which resulted in each particle making a large contribution to the external surface area and mesopore
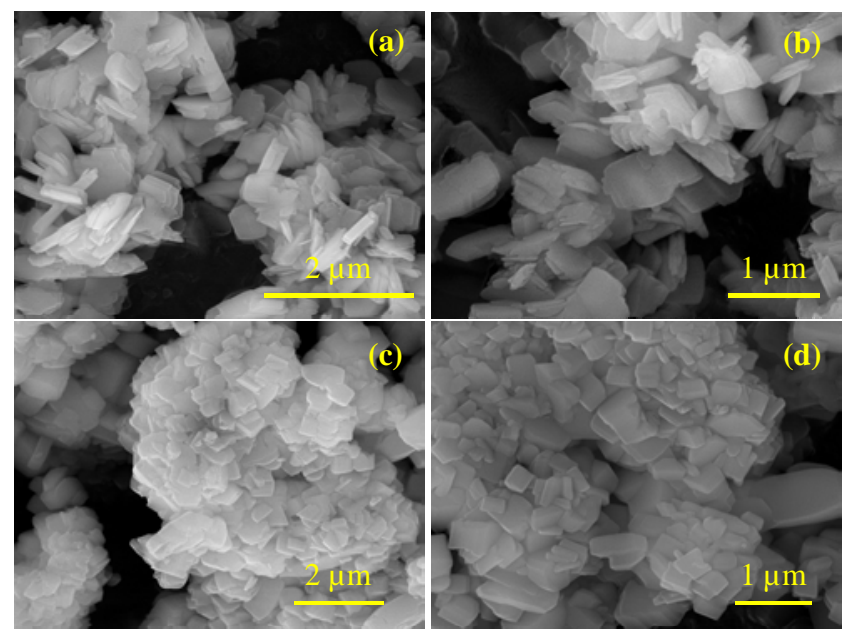

Fig. 5. SEM images of $(a, b) \mathrm{S} 2\left(\mathrm{Na}_{2} \mathrm{O} / \mathrm{SiO}_{2}=0.090\right)$ and $(c, d) \mathrm{S} 5$ $\left(\mathrm{Na}_{2} \mathrm{O} / \mathrm{SiO}_{2}=0.140\right)$.

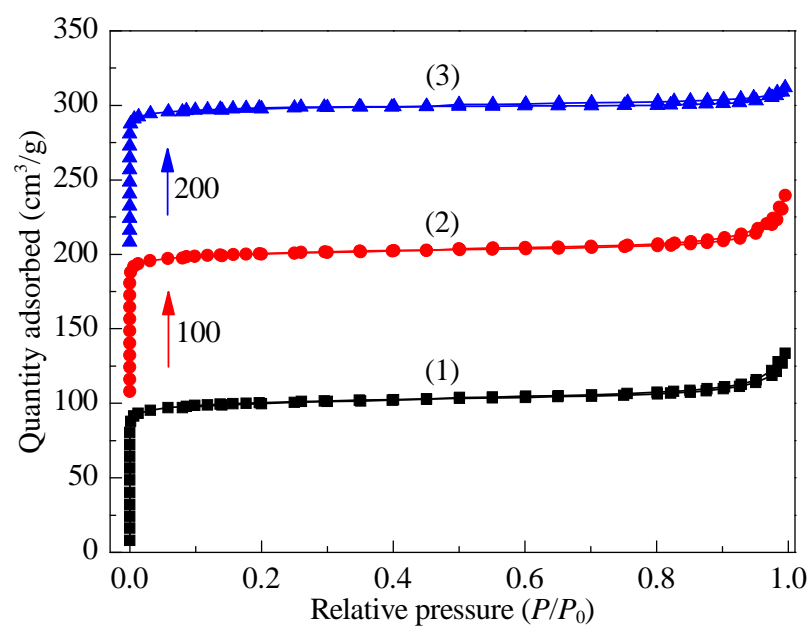

Fig. 6. $\mathrm{N}_{2}$ adsorption/desorption isotherms of FER zeolites synthesized at different alkalinities. (1) $\mathrm{Na}_{2} \mathrm{O} / \mathrm{SiO}_{2}=0.090$ (S2); (2) $\mathrm{Na}_{2} \mathrm{O} / \mathrm{SiO}_{2}=$ 0.105 (S3); (3) $\mathrm{Na}_{2} \mathrm{O} / \mathrm{SiO}_{2}=0.140$ (S5).
Table 2

Effect of alkalinity on textural properties of FER zeolites.

\begin{tabular}{lcccccc}
\hline Sample & $\begin{array}{c}A_{\text {BET }} \\
\left(\mathrm{m}^{2} / \mathrm{g}\right)\end{array}$ & $\begin{array}{c}A_{\text {micro }} \\
\left(\mathrm{m}^{2} / \mathrm{g}\right)\end{array}$ & $\begin{array}{c}A_{\text {ext }} \\
\left(\mathrm{m}^{2} / \mathrm{g}\right)\end{array}$ & $\begin{array}{c}V_{\text {tot }} \\
\left(\mathrm{cm}^{3} / \mathrm{g}\right)\end{array}$ & $\begin{array}{c}V_{\text {micro }} \\
\left(\mathrm{cm}^{3} / \mathrm{g}\right)\end{array}$ & $\begin{array}{c}V_{\text {meso }} \\
\left(\mathrm{cm}^{3} / \mathrm{g}\right)\end{array}$ \\
\hline S2 & 398 & 360 & 38 & 0.206 & 0.138 & 0.068 \\
S3 & 399 & 362 & 37 & 0.216 & 0.139 & 0.077 \\
S5 & 392 & 365 & 27 & 0.173 & 0.140 & 0.033 \\
\hline
\end{tabular}

volume. Therefore, the external surface area and mesopore volume of S2 was slightly larger than that of S5. Furthermore, the total volume of S2 was also larger than that of S5.

\subsection{Effect of water content on FER zeolite synthesis}

Water content is important in FER zeolite crystallization [37]. Well-crystallized FER zeolite without any impurity phase was obtained when the $\mathrm{H}_{2} \mathrm{O} / \mathrm{SiO}_{2}$ ratio was 14.0 (Fig. $7(2)$ ). However, FER zeolite contaminated with impurity phase, as indicated by the peaks at $25.9^{\circ}$ and $27.9^{\circ}$, was obtained when silica/aluminum species were concentrated in the initial gel mixture $\left(\mathrm{H}_{2} \mathrm{O} / \mathrm{SiO}_{2}=8.5\right)$. In contrast, a low concentration of silica/aluminum species $\left(\mathrm{H}_{2} \mathrm{O} / \mathrm{SiO}_{2}=25.0\right)$ diminished FER zeolite crystallization, affording amorphous phase with several weak diffraction peaks (S18, Fig. $7(3)$ ). When $\mathrm{H}_{2} \mathrm{O} / \mathrm{SiO}_{2}$ was further increased to 35.0, no peaks were observed in the XRD pattern. Nevertheless, well-crystallized FER zeolite was obtained by adding $5 \mathrm{wt} \%$ FER seeds to the high-water-content system (S19, Fig. 7(4)).

In summary, well-crystallized FER zeolites were successfully synthesized at $150-170{ }^{\circ} \mathrm{C}$ with the following initial gel compositions: (1.8-3.0) $\mathrm{Na}_{2} \mathrm{O}:(0.50-0.66) \mathrm{Al}_{2} \mathrm{O}_{3}: 20 \mathrm{SiO}_{2}: 3.2 \mathrm{PI}$ : $280 \mathrm{H}_{2} \mathrm{O}$. The particle size was in the range of $0.4-1.0 \mu \mathrm{m}$ and the Brunauer-Emmett-Teller (BET) surface area was around $395 \mathrm{~m}^{2} / \mathrm{g}$.

\subsection{Catalytic performance in 1-butene skeletal isomerization}

FER zeolite is a good catalyst candidate in the skeletal isomerization of 1-butene [2,5]. Herein, HS2 and HS5, obtained at

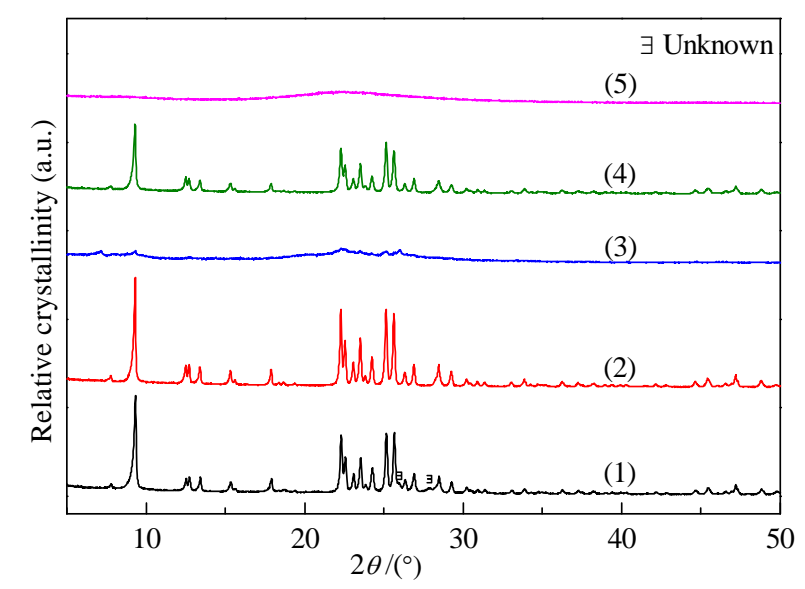

Fig. 7. XRD patterns of FER zeolites synthesized with different $\mathrm{H}_{2} \mathrm{O} / \mathrm{SiO}_{2}$ ratios. (1) 8.5 (S17); (2) 14.0 (S3); (3) 25.0 (S18); (4) 25.0 using 5\% FER seeds (S19); (5) 35.0 (S20). 

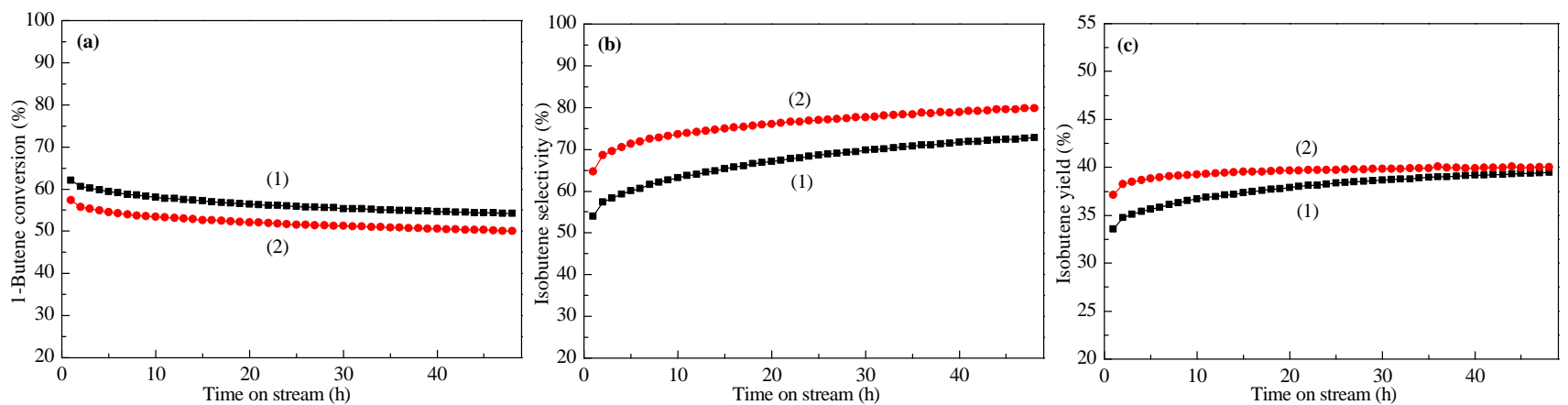

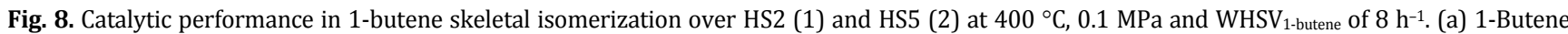
conversion; (b) Isobutene selectivity; (c) Isobutene yield.

different alkalinities, were chosen and evaluated as catalysts in the 1-butene skeletal isomerization reaction (Fig. 8). These two samples showed similar catalytic changing trends, as reported previously [6,38]. 1-Butene conversion gradually decreased with time on stream, while the product selectivity for isobutene increased with reaction time. Therefore, the isobutene yield increased with time on stream. As shown in Fig. 8(c), the isobutene yield over HS5 was slightly higher than that over HS2.

\section{Conclusions}

The crystallization behavior and optimal synthetic conditions of FER zeolites directed by PI were investigated in detail. XRD patterns and SEM images showed that product evolution was closely related to the crystallization temperature. Only the FER phase was observed during crystallization at $150{ }^{\circ} \mathrm{C}$. However, MWW phase appeared as the interphase when crystallization occurred at $160-170{ }^{\circ} \mathrm{C}$. Alkalinity proved to be the key factor in obtaining FER zeolites with controllable chemical compositions, morphologies, and textural properties. FER zeolite with a large external surface area and loosely stacked large particles was obtained at low alkalinity, while high alkalinity led to the formation of FER zeolite with closely stacked small particles. MOR and MTN were the main impurity phases produced using this synthesis system. Based on the above experimental results, the optimal initial gel compositions for FER synthesis was (1.8-3.0) $\mathrm{Na}_{2} \mathrm{O}:(0.50-0.66) \mathrm{Al}_{2} \mathrm{O}_{3}: 20 \mathrm{SiO}_{2}: 3.2 \mathrm{PI}$ : $280 \mathrm{H}_{2} \mathrm{O}$. The obtained FER zeolites exhibited good catalytic performance in the 1-butene skeletal isomerization reaction.

\section{References}

[1] P. A. Vaughan, Acta Crystallogr., 1966, 21, 983-990.

[2] W. Q. Xu, Y. G. Yin, S. L. Suib, J. C. Edwards, C. L. O'Young, J. Catal., 1996, 163, 232-244.

[3] B. de Ménorval, P. Ayrault, N. S. Gnep, M. Guisnet, Appl. Catal. A, 2006, 304, 1-13.

[4] Y. P. Khitev, I. I. Ivanova, Y. G. Kolyagin, O. A. Ponomareva, Appl. Catal. A, 2012, 441-442, 124-135.

\section{Graphical Abstract}

Chin. J. Catal., 2017, 38: 1880-1887 doi: 10.1016/S1872-2067(17)62906-1

\section{Synthesis of FER zeolite with piperidine as structure-directing agent and its catalytic application}

Weifeng Chu, Fucun Chen, Ce Guo, Xiujie Li *, Xiangxue Zhu, Yang Gao, Sujuan Xie, Shenglin Liu, Nan Jiang, Longya Xu * Dalian Institute of Chemical Physics, Chinese Academy of Sciences;

University of Chinese Academy of Sciences;

Nanjing Rongxin Chemical Co., Ltd.

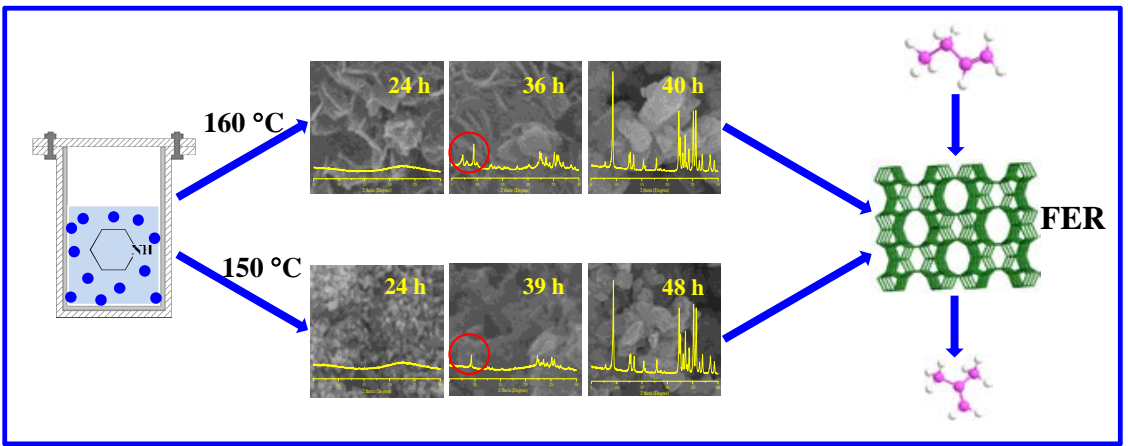

The crystallization behavior of FER zeolite is closely related to the crystallization temperature, with well-crystallized FER zeolite showing good catalytic performance in 1-butene skeletal isomerization. 
[5] D. Jo, K. Lee, G. T. Park, S. B. Hong, J. Catal., 2016, 335, 58-61.

[6] W. F. Chu, X. J. Li, X. X. Zhu, S. J. Xie, C. Guo, S. L. Liu, F. C. Chen, L. Y. Xu, Microporous Mesoporous Mater., 2017, 240, 189-196.

[7] P. Pantu, B. Boekfa, B. Sunpetch, J. Limtrakul, Chem. Eng. Commun., 2008, 195, 1477-1485.

[8] M. Mauvezin, G. Delahay, F. Kisslich, B. Coq, S. Kieger, Catal. Lett., 1999, 62, 41-44.

[9] J. L. Liu, H. F. Xue, X. M. Huang, Y. Li, W. J. Shen, Catal. Lett, 2010, 139, 33-37.

[10] X. J. Li, X. H. Liu, S. L. Liu, S. J. Xie, X. X. Zhu, F. C. Chen, L. Y. Xu, RSC Adv., 2013, 3, 16549-16557.

[11] P. Cheung, A. Bhan, G. J. Sunley, E. Iglesia, Angew. Chem. Int. Ed., 2006, 45, 1617-1620.

[12] M. A. Aramendia, V. Borau, C. Jimenez, J. M. Marinas, R. Roldan, F. J. Romero, F. J. Urbano, Chem. Lett., 2002, 672-673.

[13] J. H. Flores, M. E. H. M. da Costa, M. I. P. da Silva, Chin. J. Catal, 2016, 37, 378-388.

[14] C. L. Kibby, A. J. Perrotta, F. E. Massoth, J. Catal., 1974, 35, 256-272.

[15] B. G. Anderson, R. R. Schumacher, R. van Duren, A. P. Singh, R. A. van Santen, J. Mol. Catal. A, 2002, 181, 291-301.

[16] T. J. Kim, W. S. Ahn, S. B. Hong, Microporous Mater., 1996, 7, 35-40.

[17] X. X. Chen, T. Todorova, A. Vimont, V. Ruaux, Z. X. Qin, J. P. Gilson, V. Valtchev, Microporous Mesoporous Mater., 2014, 200, 334-342.

[18] K. Suzuki, Y. Kiyozumi, S. Shin, K. Fujisawa, H. Watanabe, K. Saito, K. Noguchi, Zeolites, 1986, 6, 290-298.

[19] A. B. Pinar, P. A. Wright, L. Gómez-Hortigüela, J. Pérez-Pariente, Microporous Mesoporous Mater., 2010, 129, 164-172.

[20] W. J. Smith, J. Dewing, J. Dwyer, J. Chem. Soc., Faraday Trans. 1, 1989, 85, 3623-3628.

[21] Y. Kamimura, C. Kowenje, K. Yamanaka, K. Itabashi, A. Endo, T. Okubo, Microporous Mesoporous Mater., 2013, 181, 154-159.
[22] S. J. Xie, J. B. Peng, L. Y. Xu, Z. H. Wu, Q. X. Wang, Chin. J. Catal., 2003, 24, 531-534.

[23] X. W. Cheng, J. Wang, H. Yu, J. Guo, H. Y. He, Y. C. Long, Microporous Mesoporous Mater., 2009, 118, 152-162.

[24] X. W. Cheng, J. Wang, J. Guo, H. Y. He, Y. C. Long, Microporous Mesoporous Mater., 2009, 119, 60-67.

[25] T. Xue, H. P. Liu, Y. M. Wang, RSC Adv., 2015, 5, 12131-12138.

[26] P. Wuamprakhon, C. Wattanakit, C. Warakulwit, T. Yutthalekha, W. Wannapakdee, S. Ittisanronnachai, J. Limtrakul, Microporous Mesoporous Mater., 2016, 219, 1-9.

[27] R. K. S. Almeida, L. Gómez-Hortigüela, A. B. Pinar, J. Peréz-Pariente, Microporous Mesoporous Mater., 2016, 232, 218-226.

[28] H. Jongkind, K. P. Datema, S. Nabuurs, A. Seive, W. H. J. Stork, Microporous Mater., 1997, 10, 149-161.

[29] G. Pál-Borbély, H. K. Beye, Y. Kiyòzumi, F. Mizukami, Microporous Mesoporous Mater., 1998, 22, 57-68.

[30] G. Pál-Borbély, Á. Szegedi, H. K. Beyer, Microporous Mesoporous Mater., 2000, 35-36, 573-584.

[31] B. Zhang, Z. D. Wang, H. M. Sun, W. M. Yang, P. Wu, Chem. React. Eng. Technol, 2013, 29, 19-23.

[32] J. Grand, H. Awala, S. Mintova, CrystEngComm, 2016, 18, 650-664.

[33] D. Nuntasri, P. Wu, T. Tatsumi, J. Catal., 2003, 213, 272-280.

[34] S. J. Xie, S. L. Liu, N. N. Gao, X. J. Li, Y. Gao, K. F. Liu, L. Y. Xu, New J. Chem., 2014, 38, 2514-2521.

[35] S. J. Xie, S. L. Liu, Y. Liu, X. J. Li, W. P. Zhang, L. Y. Xu, Microporous Mesoporous Mater., 2009, 121, 166-172.

[36] H. J. Wei, S. J. Xie, K. F. Liu, W. J. Xin, X. J. Li, S. H. Liu, S. M. Gu, S. L. Liu, L. Y. Xu, Chin. J. Catal., 2015, 36, 1766-1776.

[37] Y. Y. Hu, C. Liu, Y. H. Zhang, N. Ren, Y. Tang, Microporous Mesoporous Mater., 2009, 119, 306-314.

[38] B. T. Yang, J. G. Jiang, H. Xu, Y. M. Liu, H. G. Peng, P. Wu, Appl. Catal. A, 2013, 455, 107-113.

\title{
以哌啶为模板剂合成FER分子篮及其催化应用
}

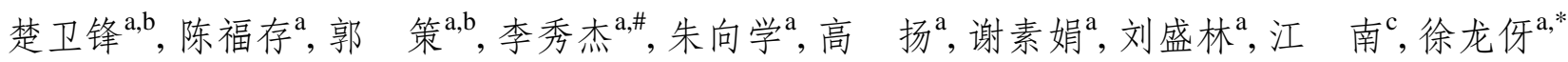 \\ a 中国科学院大连化学物理研究所, 辽宁大连 116023 \\ $\mathrm{b}$ 中国科学院大学, 北京100049 \\ c南京荣欣化工有限公司, 江苏南京 210047
}

摘要: 镁碱沸石(FER结构)是一种中孔沸石, 具有垂直交叉的二维孔道系统. 其一为沿[010]方向的八元环孔道 $(0.35 \mathrm{~nm} \times$ $0.48 \mathrm{~nm})$, 另一为沿[001]方向的十元环孔道 $(0.42 \mathrm{~nm} \times 0.54 \mathrm{~nm})$. FER分子篮是工业化的沸石催化剂之一, 主要应用于1-丁 烯骨架异构化反应. 此外, FER分子笚在氮氧化物分解和还原、二甲醚炭基化、甲醇制烯烃、烷烃加氢异构以及正构烷烃 裂化等反应中也表现出极大的应用价值.

FER分子篮通常在有机模板剂的辅助下合成. 常用的有机模板剂主要为有机胺化合物, 包括乙二胺、吡咯烷、吡啶和 环已胺等化合物. 四氢呋喃等含氧化合物也可以用于导向FER分子篮的合成. 此外, 通过两种不同尺寸的有机分子进行组 合, 也可以导向合成FER分子篮, 且这些分子篮往往具有独特的物化性质和催化性能. 以哌啶和四甲基氢氧化铵为组合模 板剂, 可以得到多级孔FER分子篮. 与粒径较大的FER分子篮相比, 其在低密度聚乙烯催化裂解反应中表现出更为优异的 催化性能. 以吡咯烷和有机硅烷为组合模板剂, 可以得到多级孔FER纳米片团簇. 与传统的微米FER分子篮相比, 该多级孔 FER纳米片团簇在甲苯与芐氯的芐基化反应中的催化活性得到显著提高. 最近, 有研究者以 $1,6-$ 双 ( $N$-甲基吡咯烷)己烷和 四甲基铵离子为组合, 同样得到了FER分子篮.

本文以哌啶为有机模板剂合成了FER分子篮, 详细考察了合成参数(碱度、水含量)和晶化条件(晶化温度、晶化时间) 对FER分子篮合成的影响. 结果表明, 温度对FER分子篎的晶化过程影响比较大. 在 $150{ }^{\circ} \mathrm{C}$ 晶化时, 只有FER分子篮出现在 其晶化过程中; 在 160 或 $170{ }^{\circ} \mathrm{C}$ 晶化时, 其晶化过程伴随有 $\mathrm{MWW}$ 分子篮的生成和消失. 高温有利于FER分子篎的晶化, 但 其易于转化为其它杂相. 凝胶硅铝比为 40.0 时, 合成纯相FER分子篎的碱度比较高; 而凝胶硅铝比为 30.3 时, 合成纯相FER 分子笁的碱度比较低. 在低碱度晶化时, 不同硅铝比的凝胶出现的杂相也不尽相同. 凝胶硅铝比为 40.0 时, 其产物为FER分 
子篮与MTN分子篮的混合物; 而凝胶硅铝比为36.4时, 其产物为MWW分子篮与MTN分子篮的混合物. 水含量对FER分子 笁的合成影响也比较大. 当水含量较低时, 其产物容易出现其它杂相; 当水含量较高时, 其产物为无定形物质. 通过向高 水含量的体系中添加FER晶种, 可以得到高结晶度的FER分子篮. FER分子笁的化学组成、形貌和织构性质与初始凝胶的 碱度密切相关. 初始凝胶碱度较低时, 产物的硅铝比较高, 外表面积较大, 一次粒子粒径较大且堆积疏松; 初始凝胶碱度较 高时, 产物的硅铝比较低, 外表面积较小, 一次粒子较小且堆积紧密. 此外, 以哌啶为模板剂合成的FER分子篮在1-丁烯骨 架异构化反应中表现出优异的催化稳定性和较高的异丁烯收率.

关键词: FER分子篮; 哌啶; 晶化过程; MWW分子篮; 骨架异构化

收稿日期: 2017-07-23. 接受日期: 2017-08-24. 出版日期: 2017-11-05.

*通讯联系人. 电话/传真: (0411)84379279; 电子信箱: lyxu@dicp.ac.cn

\#通讯联系人. 电话/传真: (0411)84379279; 电子信箱: xiujieli@dicp.ac.cn

基金来源：国家自然科学基金(21376235); 辽宁省自然科学基金(201602740).

本文的电子版全文由Elsevier出版社在ScienceDirect上出版(http://www.sciencedirect.com/science/journal/18722067). 